\title{
Genesis of Indian Culture: Akbar Quest for Unity in a Traditional Society
}

\author{
Rukhsana Iftikhar
}

\begin{abstract}
Cultural studies construct and theorize those forces around which the whole human life revolves. A few indicators of culture that exist in society are literature, poetry, architecture, visual arts etc. It became a discipline from 1964 to onward. Cultural studies combine every aspect of society by relating social norms, customs, tradition, religion, language, food and arts with politics and economy. Sometimes tools of culture used by the power to meet the political ends. Indian culture is multi dimensional having various shades of religious identities like Hinduism, Buddhism, Christianity and Islam. These identities played a vital role in the development of Indian culture. Indian culture has its own significant from ancient times. In the age of empire king Asoka patronized Buddhism as state religion and introduced a unique culture. The Mughal king Akbar (1556-1605) also made an effort. Akbar successfully involved every community of India and his neighboring countries in formation of the culture of his Empire. He used every method to crystallize a unified Indian culture which was highlighted by each historian of Medieval India. It is proven that the emergence of this culture through power but the existence of this was even today testifying its popularity among masses. Akbar also delayed the process of conflict through cultural synthesis at least for his generations. This paper highlights the dynamics of material culture in age of King Akbar. It explores the involvement of different communities in the culture making and they respect the cultural norms of each other. It identifies that cultural synthesis avoid conflict in traditional society like India.
\end{abstract}

Index Terms-Hindustan, Ain-i-Akbari, Urdu, Hindi, Hamzanama, Bakawal, Ganga.

\section{INTRODUCTION}

Indian civilization is considered one of the ancient civilizations having unique culture. This culture is the result of various forces like Greek, Sakas, Khushans, Huns, and eventually Muslim operating from many millenniums. They contributed in the evolution of its culture. Therefore this region is endowed with a dynamic culture which has exceptional vitality. Indian culture is amalgamation of Hinduism, Buddhism, Christianity and Islam. The interaction among different communities provided a vast spectrum to flourish Hindustani Culture as Jawarlal Nehru commented, "Two close systems, each of them has its own strong roots, could develop a healthy relations."[1] This union gave birth to a new language called "Urdu".

Manuscript received October 24, 2014; revised December 26, 2014.

Rukhsana Iftikhar is with the Department of History \& Pakistan Studies, University of the Punjab, Lahore, Pakistan (e-mail: rukhsana234@yahoo.com).

\section{LITERARY WORKS}

The works of Amir Khusru, Malik Muhammad Jayasi, Ras Khan and Tulsi Das were the incredible creations of this new language. [2] For three centuries (1200-1500) the intellect of India was not recognized properly. Mughal King Akbar gave a literary stimulus to literature and the men of literary taste. Persian became the court language. He initiated historical works for preservation of his dynastical record. Being illiterate king fourteen historical works were written in his period expect one (Muntakh-bul- Tawarikh of Mulla Abul Qadir Badaoni) all got royal favor. The work of translation made their mark on the pages of history. The Lilwati, most excellent work of Indian mathematicians on arithmetic and Nal Daman translated by Fayzi, a well known work on Astronomy Tajak was translated by Mukammal khan of Gujarat. Mirza Abd-ur- Rahim translated Babur's memoirs from Turkish to Persian language. The history of Kashmir has been translated into Persian by Shah Muhammad Shahabadi. The Mujam -a- Baldan, work on town and countries translated from Arabic to Persian in the supervision of Qasim Beg and Shiekh Manawar. Maulana Sheri translated Haribas, the story of Lord Krishna from Hindi to Persian [3].

Akbar's reign is marked as new epoch in the literary history of India. Abu Fazal enumerates seventy five poets who came to India during the time of his majesty. He wrote, "The inspiring nature of his majesty is a strongly drawn to the composing of Hindi and Persian poetry". Sometimes he composed verses in Persian,

1) In Majnu's neck is not a chain to restrain of his madness:

2) Love hath put the arm of friendship round his neck [4].

3) Akbar learned Diwan -a-Hafiz by heart. Once his courtier made some mistake he corrected his noble in such a manner.

4) In such fashion comes my glorious horsemen o Fighani.

5) Akbar patronized number of poets came from far wide. Most of them migrated from Persia. Taqat-a-Akbari gives a list of eighty one poets and Muntakh-bulTawarikh mentioned 168 poets in the court of King Akbar [5]

\section{A. Painting}

In the field of fine arts Mughal dynasty has a richest contribution. Akbar was the founder of painting studio in Middle Ages although his ancestors brought Bihzad (painter) with them from central Asia. There was a galaxy of painters in the court of Akbar from Iran (Mir Sayyid Ali, Khwaja Abud Samad), Khursan, Bukhara and India (Daswant\&Basawan). The illustrated copies of Hamzanama 
and Zafarnama, Razmnama, Ramayana, Nal Daman, Kalilah Damnah, Ayar Danish were prepared under this painting studio. It also led to the development of sub styles Rajput and Phari which were greatly influenced by ancient styles of Indian paintings [6].

\section{B. Calligraphy}

In the field of calligraphy Akbar excelled to the glory. Babur,the founder of Mughal dynasty invented,Khat-i Babari. Akbari followed the foot step of his forefathers. Fayzi wrote the interpretation of Quran without dots. Shah Mahmud of Nishapuri, Mahmmad Ishaq, Abd-ur- Rahim of Khwarizm , Muhammad Husain of Tabriz, Miza Ibrahim of Isfahan devoted their lives for art of calligraphy. Abul Fazal (court Historian of Akbar) gave a long list of various calligraphists who migrated into India and got the favor of his majesty in art of calligraphy. They brought perfection this art. Akbar appointed these painters and calligraphists during (1570-1585) who established Mughal schools of paintings and calligraphy [7].

\section{Architectural Styles}

Architectural styles of Akbar's age were the fusion of Hindu, Transoxia, Iran, Afghan and Arabic which are reflected through the fort of Agra, Fatehpur Sikri, Arab Sarai, Ajmer Fort, Allahabad fort and Lahore Fort. Many architectural styles were influenced by secular art like Hinduism and Buddhism. The Raniwas and temple attached to the queen palace indicates his liberalism in accommodation of other believers. [8] His period was the region of secular architecture. Akbar was impressed by Buddhist architecture. The concept of arches and doom was taken from Buddhist buildings. The first reference of doom in India was of a Buddhist stupa called Sanchi. The lotus flower art was very much in use especially in blue color to decorate the arches of building during his period is pure form of Buddhist art. The arches were taken as a symbol and his power symbolized absolute power of Buddha which is explained in their teachings of Tri Ratna. The absolute power comes from the top arch (Buddha) then to his disciples or Dharma and then the administration of Sangha. The railings in buildings of that age were the Buddhist style. Buland Darwaza is a master piece of Akbar age highlights his religious broad mindedness [9].

\section{Music}

Abul Fazal provided a list of 36 musicians in the court of Akbar and Mian Tansan of Gwalior was legend among them. Akbar awarded him 200,000 on the eve of his first performance. Music as a talisman of knowledge Akbar appointed many musicians from different origins including Hindus, Irani ,Turani and Kashmirs. Females who were performed in harem and private assemblies of Mughals, Akbar gave them a reasonable name, "Kanchains". Mann Singh's wife Mrignayni was expert in music. Ain-i-Akbari mentioned those local instruments which were used in the court performances. [10] The celebrations of fairs and festivals were important regarding his policies to involve every community in the social life of India. Mughal celebrated Nauroz, a festival of purely Iran on the eve of new year. Akbar converted it into khushroz (joyful day). He followed the custom of Parsees who held banquets on those days, the names of which coincided with the names of month. He made Holi, one of the ancient festivals of Hindu an event of official celebration. Abul Fazal narrated, on this day many cows were ornamented and presented before his majesty. He also celebrated, Rakhi, Dipawli, Deshra and Vasant due to his alliance with Hindus [11].

\section{E. Fashion and Diet}

His ascetic taste reflected through the style of costumes. Father Monserrate wrote about the dress of Akbar" his majesty wore clothes of silk beautifully embroidered in gold. His majesty clock came down to his hose and boots covered his ankles completely and he also wear pearls and gold jewelry". [12] Father Rudolf found Akbar in a Hindu dhoti the "finest and most delicate silk falling to his heels and there gathered by bangles covered with pearls". [13] Akbar also changed the names of several garments. This show his predilection for Hindu terms like Jama was replaced by Sarbgati (a dress covered the whole body), Izar (yar pirhan) trouser, nimtana (tanzeb) jacket, burqa (Chitrguptia) veil, Kula (sis-sobha) cap, patka (katzeb) a cloth for loin, shawl (pargarm), pay -afzar(charndharn) shoes. Akbar adopted different colors for different days of week in respect of seven colors of seven plants [14].

As far as the matter of food is concerned Mughal had a proper establishment of kitchen under the supervision on Mir Bakawal. Akbar didn't like meat and took it occasionally to "conform to the spirit of the age". The days of abstinence (sufiyana) indicates that Akbar was not in favor of slaughtering animals and killing them for the purpose of food. Akbar used to commence his meal with milk and curd. Fruits for his kitchen were imported from Turan, Kabul,Qandahar and Kashmir. Akbar took keen interest in bakery. Mughla cuisine was the mixture of Central Asian and Indian food. [15] Mughals were in habit of taking intoxication. Akbar was sober in his drinking parties but it is said that once Akbar lost control and saved in the nick of time by Raja Maan Singh when under the influence of liquor he tried to demonstrate his bravery in Rajput fashion [16] Father Ridolof confirmed, "Akbar used to take post, preparation of opium, diluted and modified by various mixtures of spices". [17] He also enjoyed Tobacco in spite of his physician's advice that it was not good for his health. Portuguese introduced Tobacco in Indian sub- continent. A separate department of water and ice (Abdar-Khanah) was maintained for the Emperor. Akbar used "Gangajal" for drinking purposes. When Akbar resided in Agra and Fatehpur Sikri , Gangajal brought from Soron ( Uttar Pradesh). When he made Lahore his capital then water was supplied from Haridwar. The water of Jumna and Chenab used for cooking. Ice was the luxury of his age only available for the kings and some of his nobles because it was brought directly from Panhan the northern mountains [18].

\section{F. Recreation Activities}

Emperor spent some of his time in those activities which gave him physical strength and relaxation. Chugan was popular in Persia; Akbar revived this game in India. He invented fiery balls (illuminated balls) to play this game in dark nights. He also added splendor in this game. He had 
knobs of silver and gold in the chugan sticks. The most famous play ground was prepared in capital city. [19] Akbar was also fond of boxing. He kept large number of Turani and Iranian boxers in court. Akbar ordered, wrestling to be held every day in his presence in the court. Akbar invented a special kind of hunting exercise called Qumargaha which became very popular in Mughal India. A special amphitheatre for animal fighting was prepared under the command of Akbar. Emperor was fond of elephant fighting and sometimes he personally took part in it. It was generally held twice a week on Tuesday and Saturday for the amusement of the King. It was quite visible from the balcony of royal palace over the Darshani gate in Agra fort. [20] This practice was common in Roman Empire to see the fight of animals as well as human in colossal.

\section{G. Alliances}

Akbar's marriages with Rajput princess were considered turning point of his policy of peace and stability of his Empire. His marriage with Raja Bharmal of Amer (Jaipur, Rajasthan) set a trend in this regard. Akbar gave her the title (Maryum-u-Zamni) and she enjoyed the freedom to follow her own religious doctrines. She used to pray in her temple still visible in the interior of Fatehpur Sikri. Later on Raja Kalyan Mal of Bikaner offered his niece to Akbar. He also accepted the proposal of the daughter of Rawal Hai Rai of Jaislmer. These relationship with locals consolidated Mughal Empire I. H. Quershi commented, "Akbar secured three generations of Mughls against Raj put power through his policy." [21] He also defined some rules and regulations for marriages. He didn't like cousin marriages and four marriages for common man as Islam permitted Muslim as it ruins man's health and disturb the peace of home. He was influenced by the idea of single marriage in Christianity. He was against child marriages that are why he declared the age of marriage 12 years for girls and [14] years for boys. He established an office under Tu-i-begi to inquire the age of bride and groom before entering into the contract of marriage. Akbar holds a high opinion of the chastity of Hindu women" that in spite of being sometime neglected, are flaming torches of love and fellowship". [22] He disapproved high dowries but he also admitted that, "high dowries is a prevent against rash divorce". Akbar is said to have ordained that a village officer presented two coconuts, one their own behalf and other on the behalf of the Mughal Emperor [23].

Akbar appointed a number of Hindus on the highest post of his admistrative system. Most of the Akbar officers were foreigners mostly from Persia and Afghans. But a fair number of his officers from Hindus like well-known Raja Todar Mall as his finance minister, Raja Mann Singh(C-in C) of Mughal Army. Abul fazal disclosed this fact there were 51 Hindu ministers among 415 mansbdars of Akbar. [24] Emperor Akbar is bitterly criticized on his religious policies. Every historian made it point to marginalize the personality of Akbar. This new religion Tauhid-a-Illahi introduced some customs of greetings each other, celebration of birthdays, distribution of alms and charity on specific days, taking non vegetarian meals on occasions etc. Scholars have developed a consensus that Akbar's religious policy was the outcome of his discussions in Abbat-Khana (place of worship). He invited the religious scholars of Hinduism, Buddhism, Parsees and Christianity. Akbar had cordial relations with communities of India He invited father Rudalfo, Aquaviva, Antonio de Monserrate, Farancisco Enriques from Goa. He appointed them for the education of his childrens Salim and Murad Murad. [25] Akbar also followed the ritual of Zoroastrian doctrine. Abul Fazal made special arrangements in the court for fire day and night as in the court of Persian kings, "fire is the manifestation of God". He used to participate in a special custom of Hom in his youth show his affection towards Hindu princess of his Harem. He worshipped sun and fire as he ordered to all of courtiers to stand up when the lights and lamps of his palace were lightened. He made Hindu mark on his forehead as a sign of luck. Reading and writing of Arabic was forbidden. Astronomy, Mathematics, Medicines, History, Mathematics and Philosophy were given preference upon other studies [26].

Akbar legalized many things during his region like selling and purchase of wine for the sake of disease. He channelized prostitution through office of Darogah and maintained a register of Shaitanpura (devil villa). [27] He regularly shaved his beard due to his liaison with Hindus. At the time of natural catastrophes parents were allowed to sell their children in the markets but they could get them back after the payment to their masters. No one was allowed to interfere in the religions of others. If Hindu women fell in love with Muslim man she should not forced to change her religion. All Indians were allowed to build their places of worship like churchs, temples and fire houses. [28] Some of the etiquettes and manners had also changed under the influence of this religious pluralism. Kornish and Taslim became the part of court's appearances. Akbar insisted that Taslim should be repeated thrice in the court. He also introduced Sajjdah especially for those who were his disciples but this was not practice in public assemblies but in private meetings. The practice of King's appearance in public (Jharoka Darshan) was also in vogue. The motive behind this custom was people should start their daily doings to have a look at the auspicious face of King. [28] Akbar religious views did not extend beyond the year of 1596. As his son commentated, his father died as a Muslim. The spirit behind his religious policy was toleration and his subject remained passive. This spirit died out after his death.

\section{CONCLUSION}

Zaheer-ud-din Babur founded the rule of Mughal dynasty but Akbar policy of consolidation was materialized through his cultural cohesion. A traditional society like India he made it possible to avoid conflict by patronizing every religious community of his Empire. Many historians alleged him as an atheist by criticizing his religious policy. But his age was an amalgamation of various cultures. Akbar celebrated their festivals, adulated their living style, adopted their manners just to develop liaison. His cultural mechanism sorted out their problem of clashes. On the basis of their religious or ethnic identities Akbar's rule presented a matchless example in the history of kingship. 


\section{REFERENCES}

[1] J. Lal Nehru, The Discovery of India, Penguin Books, 2004, p. 285.

[2] K. M. Asharf, Life and Conditions of People of Hindustan, Delhi, Munshi Mahorlal Publisher, 1959, p. 81.

[3] H. Hussain, "Mughal poetry: Its cultural and historical value," Indo Iranica, 1957-1963, p. 26.

[4] M. A. Ghani, A History of Persian Language and Literature at the Court of Mughals, Allahabad, 1930, PP. 39-66.

[5] D. Hafiz and M. A. Q. Badaoni, "British Museum 661-62," Muntakh-bul-Tawaikh, Delhi, 2001, vol. III, pp. 299-310

[6] A. Fazal and H. Blochmann, Ain-i-Akbari, (Trans.) Lahore, Low Price Publication, 2001, vol. I, pp.102-105.

[7] A. Fazal and H. Blochmann, Ain-i-Akbari, (Trans.) Lahore, Low Price Publication, 2001, vol. I, pp. 113-115.

[8] R. Nath, Private Life of the Indian Mughals, Delhi, Rupa\&co, 2005, pp. 14-15.

[9] S. A. N. Razvi, Fathpue Skiri Revisited, Oxford university press, 2013, pp. $45-46$.

[10] A. Fazal, Ain-i-Akbari, vol. II, pp. 680-681.

[11] M. P. Srivastava, Social Life under the Great Mughals, Allahabad, 1978, pp. 43-44.

[12] J. S. Monserrate and S. K. Banjerji, The Commentary, Oxford University Press, 1922, p. 198.

[13] G. H. Anderson, Biographical Dictionaries of Christian Missionaries, Cambridge university press, 1999, pp. 4-5.

[14] A. Fazal, Ain-i-Akbari, vol. 1, p. 96.

[15] R. Nath, Private Life of the Mughals of India, Delhi, Rupa\&co, 2005, p. 93.

[16] P. N. Chopra, Life and Letter under Mughals, Delhi, 1975, p. 39.

[17] J. S. Monserrate and S. K. Banjerji, The Commentary, Oxford University Press, 1922, p. 199.

[18] A. Fazal, Ain-i-Akbari, vol. 1, pp. 55-56.
[19] A. Fazal, Ain-i-Akbari, vol. 1, p. 309.

[20] N. Jayapalan, Social and Cultural History of India Since 1556, Atlantic publishers and distributors, 2000, p. 6.

[21] I. H. Qureshi, Akbar the Architect of Mughal Empire, Book traders, Lahore, p. 65.

[22] A. Fazal, Ain-i-Akbari, vol. 1, p. 227, vol. 2, p. 616.

[23] A. Fazal, Ain-i-Akbari, vol. 1, p. 228.

[24] A. Fazal, Ain-i-Akbari, vol. 2, pp. 604-605.

[25] M. R. Choudhary, Din-i-Illahi or the Relgion of Akbar, Calcutta, C.U Press, 1941, pp. 170-174.

[26] S. R. Shrama, The Religious Policies of Mughal Emperors, Delhi, Munshiram Mahorlal Publishers, 1988, p. 45, p. 74.

[27] V. A. Smith, Akbar the Great Mogal, People Publishing House, pp. 158-160.

[28] M. Ali, Mughal Court, Book Traders, 1976, pp. 32-35.

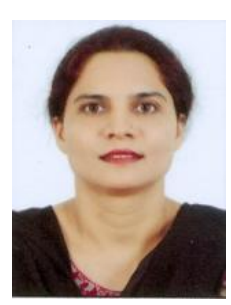

Rukhsana Iftikhar is an assistant professor of Department of History and Pakistan Studies at University of the Punjab, Lahore Pakistan. She received a Ph.D. in 2008, and did post doctoral research from 2011 to 2012 at Royal Holloway, University of London. U.K. Her field of specialization is Indian history. Dr. Iftikhar has 12 years experience in the field of education and research. She has published 14 articles in the national and international journals. She has presented her paper in Istanbul, India and America in the conferences of the history, recently her paper titled "Colonial legacies: Women education under colonial rule received a certificate merit in an international conference held in Rome. Her areas of research interest are medieval and post colonial India. 